\title{
Review
}

Source: The Musical Times and Singing Class Circular, Vol. 39, No. 661 (Mar. 1, 1898), p. 186 Published by: Musical Times Publications Ltd.

Stable URL: http://www.jstor.org/stable/3367632

Accessed: 08-05-2016 04:53 UTC

Your use of the JSTOR archive indicates your acceptance of the Terms \& Conditions of Use, available at

http://about.jstor.org/terms

JSTOR is a not-for-profit service that helps scholars, researchers, and students discover, use, and build upon a wide range of content in a trusted digital archive. We use information technology and tools to increase productivity and facilitate new forms of scholarship. For more information about JSTOR, please contact support@jstor.org.

Musical Times Publications Ltd. is collaborating with JSTOR to digitize, preserve and extend access to The Musical Times and Singing Class Circular 
Song of Night (Nachtlied). Composed for Chorus and Orchestra. By Robert Schumann (Op. Io8).

[Novello, Ewer and Co.]

ConduCTORs of choral societies should give attention to this "Song of Night," for it is music that would be enjoyed by all trained vocalists. It is laid out for the usual four voices, but occasionally these are divided into two parts. The vocal writing is easy to read and frequently of great beauty, especially towards the close of the work. Hebbel's poem has been excellently translated by Miss G. E. Troutbeck, who has fitted her words to the music with remarkable skill; and although an orchestra is required to do full justice to the work, a sympathetic pianist could make the well arranged pianoforte part very effective.

The Orpheus (New Series). Nos. 305 and 306. [Novello, Ewer and Co.]

Two attractive additions have been made to this series. The first is a four-part song for male voices entitled "Harmony," the words written by E. Taylor and the music composed by W. Beale. The text is cleverly treated and the part-writing interesting. The second is a setting by Hamilton Clarke, in the form of an unaccom panied quartet for male voices, of Shakespeare's song, "Hark, hark! the lark." The music is in Mr. Clarke's most melodious manner and will present no difficulties to fairly trained singers.

$=\frac{\text { MUSIC IN BIRMINGHAM. }}{\text { (FROM OUR OWN CORRESPONDENT.) }}$

MESSRS. HARRISON'S third concert of the present series was given in the Town Hall, on January $3 \mathrm{I}$. The artists included Miss Evangeline Florence, Miss Clara Butt, Mr. Edward Lloyd, and Mr. Watkin Mills ; Lady Hallé, Miss Adela Verne, and Mr. F. A. Sewell (accompanist). Mr. C. W. Perkins gave several organ solos with his customary skill. Lady Hallé's perfect art of violin playing was fully shown in Vieuxtemps's Fantaisie Caprice. The pianist possesses an exquisite touch and admirable style.

Mr. George Halford's sixth and seventh orchestral concerts were given in the Town $\mathrm{Hall}$, on the rst and I5th ult. Mr. Halford has always some novelties of interest to bring forward, and he has of late introduced a number of highly original works by Russian and other composers, including Dvorák's Violoncello Concerto (Op. 104), admirably played by Mr. Carl Fuchs, of Manchester ; Overture, "A Dream on the Volga" (Arensky); Entr'acte, "L'Orestie" (Tanéiëw) ; Overture, "La Patrie" (Bizet); Suite, No. 3, Op. 55 (Tschailkowsky); Overture, "Carnaval Romain" (Berlioz). At the latter concert Miss Olga von Broemsen made her début as a vocalist and gave a sympathetic rendering of songs by Tschaikowsky, Chaminade, Bohm, and Brahms.

The Festival Choral Society's second orchestral concert was given in the Town Hall, on the $4^{\text {th }}$ ult., Dr. C. Swinnerton Heap conducting. The principal novelty consisted of Tschailkowsky's piquant suite de ballet, "Casse Noisette." The performance was a very fine one throughout. Schumann's Symphony, No. I, in B flat; Beethoven's Overture, "Coriolanus"; Grieg's "Im Herbst"; and Liszt's "Hungarian Rhapsodie," No. 3, in $\mathrm{D}$, were the orchestral numbers. Mr. Willy Hess, a consummate artist in every way, played Spohr's dramatic Violin Concerto (Op. 47) and Vieuxtemps's Ballade and Polonaise in G. Miss Lilian Coomber, who took the place of Madame Ella Russell (indisposed), possesses a high soprano voice of a splendid ringing quality and is destined to make her mark in the musical world.

Dr. Rowland Winn's third orchestral concert took place in the Town Hall, on the Ioth ult. Dr. Winn gave an admirable programme of music, which included Beethoven's Fourth Symphony, Wagner's Overture to "Die Meistersinger," the Good Friday music from "Parsifal," and Grieg's Concerto for pianoforte and orchestra. Miss Fanny Davies gave a truly magnificent performance of the concerto; Madame Emily Squire was the vocalist and sang Handel's "Hush, ye pretty warbling choir," from "Acis and Galatea," and three songs by Grieg.
The Birmingham Choral Union gave a performance of "The Messiah" in the Town Hall, on the 5 th ult., under Mr. Thomas Facer's conductorship. The principals were all local artists, and Mr. C. W. Perkins presided at the organ.

The Birmingham Choral and Orchestral Association, conducted by Mr. Joseph $\mathrm{H}$. Adams, gave an interesting concert in the Town Hall, on the 7 th ult. The principal artists included Miss Emilie Long (soprano), Mr. W. Molineaux (tenor), and Mr. William Bennett (bass). The chief piece consisted of Henry Smart's dramatic cantata "The Bride of Dunkerron," written for the Birmingham Festival of 1864 , the performance of which reflected great credit on all concerned. Mr. Adams, in reviving works by British composers which are seldom heard, is doing good service in the cause of music.

Mr. Max Mossel's second drawing-room concert attracted a large audience to the Grosvenor Rooms of the Grand Hotel, on the I 7 th ult. The performers were Madame Ivan Mossel (pianoforte), Mr. Max Mossel (violin), Mr. Ferrir (viola), Mr. Ivan Mossel (violoncello). The vocalist was Madame Marian McKenzie. The chief pieces of an interesting programme consisted of Tschaïkowsky's Trio in A minor (Op. 50), Beethoven's "Serenade" Trio, and Boëllmann's "Variations Symphoniques" for violoncello. The concert was of the highest artistic standard.

\section{MUSIC IN BRISTOL.}

(FroM OUR OWN CORRESPONDENT.)

ON January 22 the newly-established Bristol and Clifton Philharmonic Society gave its first concert and brought forward Sullivan's "Prodigal Son," a work that has not been given in our city for a long time, and was therefore now heard with renewed interest. A good performance of the work was given, the members of the choir singing with taste and precision, and the chief artists, Miss Florence Cromey, Madame Barrett-Stone, Mr. E. T. Morgan, and Mr. Montague Worlock ably discharged their duties.

Messrs. Brodsky, R. Briggs, S. Speelman, and C. Fuchs visited Clifton on January 29 and gave a performance of chamber music with that excellence which characterises their efforts. Madame Darmaro, at whose instance the Manchester executants were induced to come to our city, assisted in Beethoven's Trio for pianoforte and strings in C minor (Op. I, No. 3 ).

Mr. D. W. Rootham's choir, formed chiefly of members of the musical festival choir, sang Cowen's "Sleeping Beauty," on the I8th ult., aided by Mrs. Hutchinson, Miss Lilian Hovey, Mr. Herbert Grover, and Mr. Arthur Wills. On this, the first public appearance of the newly organised body, a distinct success was achieved, Cowen's melodious and graceful work being sung with precision and expression, under the guidance of the esteemed festival chorusmaster. In the second part, containing miscellaneous vocal compositions, the choir exhibited its skill, unity, and refinement in singing part-songs and glees and some vocal waltzes by Brahms.

The Annual "Ladies' Night" of the Bristol Royal Orpheus Glee Society took place on the $I 7$ th ult., and was attended by the customary brilliant success. Under the direction of Mr. Riseley the pieces in the excellent programme, many now done for the first time by the Society, were sung with a degree of excellence bordering on perfection. Mr. Braxton Smith was the soloist.

\section{MUSIC IN DUBLIN.}

(FROM OUR OWN CORRESPONDENT.)

The inaugural concert of the new Dublin Glee and Madrigal Union was given at the Antient Concert Rooms on January 26. The members of the Union are Messrs. J. R. Morgan (alto), Mr. Melfort d'Alton (tenor), Mr. T. F. Marchant, and Mr. Harris-Watson (first and second basses). Mrs. Scott Ffennell, Mrs. Louis Mantell, Signor Esposito and Signor de Angelis contributed solos, vocal and instrumental; and Mr. C. G. Marchant conducted.

The Dublin Glee Singers, a choir of sixty voices (also an offspring of the "Feis" competitions), gave their first 